\title{
Hepatic Phosphotyrosine Phosphatase Activity and Its Alterations in Diabetic Rats
}

Joseph Meyerovitch, Jonathan M. Backer, and C. Ronald Kahn

Research Division, Joslin Diabetes Center, and Department of Medicine, Brigham and Women's Hospital, and Harvard Medical School, Boston, Massachusetts 02215

\begin{abstract}
Phosphotyrosine phosphatase (PTPase) activity in rat liver was measured using a phosphopeptide substrate containing sequence identity to the major site of insulin receptor autophosphorylation. PTPase activity was detected in both cytosolic and particulate fractions of rat liver and produced linear dephosphorylation over a 15-min time course. In rats made insulin-deficient diabetic by streptozotocin treatment (STZ), cytosolic PTPase activity increased to $180 \%$ of the control values after $2 \mathrm{~d}$ of diabetes and remained elevated at $30 \mathrm{~d}(P<0.02)$. Gel filtration on Sephadex-75 revealed a single peak of activity in the cytosol in both control and diabetic animals and confirmed the increased levels. In BB diabetic rats, another model of insulin deficiency, the PTPase activity in the cytosolic fraction was increased to $\sim 230 \%$ of control values. PTPase activity in the particulate fraction of liver was also increased by 30 and $80 \%$ after 2 and 8 d of STZ diabetes, respectively. However, this increase was not sustained and after $30 \mathrm{~d}$ of STZ diabetes, PTPase activity associated with the particulate fraction in the BB diabetic rat was reduced to $\sim 70 \%$ of the control levels. Treatment of STZ diabetic rats with subcutaneous insulin or vanadate in their drinking water for $3 \mathrm{~d}$ reduced tyrosine PTPase activity in the particulate, but not in the cytosolic fraction. This was associated with a change in blood glucose toward normal. These data indicate insulin deficient diabetes is accompanied by significant changes in hepatic PTPase activity. Since tyrosine phosphorylation plays a central role in the cellular action of insulin receptor, an increase in PTPase activity may be an important factor in the altered insulin action associated with these diabetic states.
\end{abstract}

\section{Introduction}

Phosphorylation of tyrosine residues in cellular proteins is an important regulatory process (1). The insulin receptor and the receptors for several other hormones and growth factors possess intrinsic tyrosine protein kinase activity (2-5). Furthermore, an increasing body of evidence suggests that tyrosine phosphorylation plays a central role in the cellular action of growth factors receptors and oncogene products (6-8). By contrast, the physiological role of dephosphorylation of tyrosine residues by specific phosphotyrosine protein phosphatases (PTPases) ${ }^{1}$ has not been well elucidated. Specific PTPases were

Address reprint requests to Dr. Kahn, Joslin Diabetes Center, One Joslin Place, Boston, MA 02215.

Received for publication 2 December 1988 and in revised form 3 May 1989

1. Abbreviations used in this paper: PTPases, phosphotyrosine protein phosphotases; STZ, streptozotocin; WGA, wheat germ agglutinin.

J. Clin. Invest.

(C) The American Society for Clinical Investigation, Inc.

0021-9738/89/09/0976/08 \$2.00

Volume 84, September 1989, 976-983 first described in preparations of membranes in 1981 by Brautigan et al. (9) and Gallis et al. (10). Simultaneously, cytosolic forms of PTPase were identified in extracts of muscle and liver by Folkes et al. (11). In subsequent studies, PTPase activity has been detected in a variety of tissues and cell lines, both in the soluble and particulate fractions (12-18). These enzymes are distinct from phosphoserine phosphatases based on their specificity for substrates containing phosphotyrosine residues, activity in the presence of EDTA, and selective inhibition by micromolar concentration of zinc.

Little is known about the role of PTPases in physiologic and in disease states. Two lines of evidence drew our attention to the possible role of altered PTPase in diabetes. The first is the observation that in most $(19,20)$, but not all $(22,23)$ studies, insulin receptor autophosphorylation and kinase activity is decreased in animal models of type I diabetes such as streptozotocin (STZ) rats $(19,20)$ and BB diabetic rats $(20)$ in spite of increases in insulin receptor concentration. An insulin receptor defect is also one component of peripheral resistance to insulin in patients with type II diabetes. In liver, Caro et al. (24) reported defects in both insulin receptor number and tyrosine kinase activity in hepatocytes isolated from obese type II diabetics. Three recent studies have demonstrated defects in the tyrosine kinase activity of the insulin receptor in adipose tissue (25-27) and in human skeletal muscle tissue (28). Such alterations in tyrosine phosphorylation could result from a decrease in the intrinsic activity of the insulin receptor kinase or from an increase in the rate of dephosphorylation of phosphotyrosine residues. The second is the fact that vanadium, a potent tyrosine PTPase inhibitor, mimics insulin effects in isolated cells (reviewed in 29) and in STZ diabetic rats $(30,31)$. This insulin-like effect of vanadate may be due to inhibition of PTPases $(32,33)$ or a direct stimulation of the insulin receptor autophosphorylation (34).

In light of these findings, we measured PTPase activity in the liver, an important insulin responsive tissue, in two models of insulin deficient diabetes. Since cells may contain multiple PTPase activities that differ in their substrate specificity (35), we have focused our attention on the PTPase activity which may be involved in insulin receptor dephosphorylation by utilizing a synthetic substrate containing sequence identity to the major site of insulin receptor autophosphorylation, residues $1142-1153$ in the insulin receptor sequence (3). Using this approach we have measured PTPase in both the cytosolic and particulate fractions of liver from STZ and BB diabetic rats. Furthermore, we have evaluated the effect of treatment with insulin and vanadate on diabetes-related changes in PTPase activity.

\section{Methods}

\section{Materials}

$\gamma\left[{ }^{32} \mathrm{P}\right] \mathrm{ATP}(3,000 \mathrm{Ci} / \mathrm{mmol})$ was obtained from New England Nuclear (Boston, MA); [ $\left.{ }^{125} I\right]$ monoiodo- $\mathrm{A}^{14}$ insulin was purchased from Amersham Corp. (Arlington Heights, IL); and wheat germ agglutinin (WGA) agarose was from Vector Laboratories (Burlingame, CA); so- 
dium orthovanadate was from Aldrich Chemical Co., Inc. (Milwaukee, WI). Streptozotocin, Hepes, PMSF, aprotinin, leupeptin, benzamidine, $\mathrm{N}$-acetyl-D-glucosamine were from Sigma Chemical Co., (St. Louis, MO); porcine insulin was from Calbiochem (La Jolla, CA). Reagents for $\mathrm{NaDSO}_{4}$ /polyacrylamide gel electrophoresis, Bio-gel P-6, dithiothreitol, Coomassie blue G250 and Triton X-100 were purchased from Bio-Rad Laboratories (Richmond, CA). Sephadex G-75 superfine was purchased from Pharmacia Fine Chemicals (Piscataway, NJ). The synthetic peptide, Thr-Arg-Asp-Ile-Tyr-Glu-Thr-Asp-TyrTyr-Arg-Lys, which contains the amino acid sequence between residues 1142-1153 of the $\beta$-subunit of the insulin receptor, was purchased from Dr. David Coy, Tulane University, New Orleans, LA.

\section{Animals}

Male Sprague-Dawley rats weighing 180-200 g were purchased from Charles River Laboratories (Wilmington, MA). STZ-induced diabetes was induced in the rats by injecting $65 \mathrm{mg} / \mathrm{kg}$ streptozotocin in citrate buffer ( $\mathrm{pH} \mathrm{4.5)}$ via the vein tail. The rats were killed at the indicated times after induction of diabetes by cervical dislocation.

Chronic diabetic male BB rats and control diabetes-resistant rats were purchased from BB/Worcester Project, University of Massachusetts Medical School (Worcester, MA). Diabetes was diagnosed on the basis of glucosuria using TES-TAPE (Eli Lilly \& Co., Indianapolis, IN) and plasma glucose in excess of $250 \mathrm{mg} / \mathrm{dl}$.

Diabetic BB rats were treated with NPH insulin. The dose was adjusted so that the rats were hyperglycemic but nonketotic. All animals were fed ad lib. until sacrifice (between 8 and 10 a.m.).

\section{Procedures}

${ }^{32}$ P-labeling of synthetic peptide substrate. WGA-purified insulin receptor preparations isolated from rat liver were prepared as previously

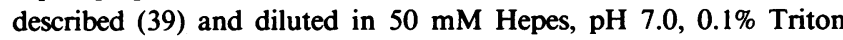
$\mathrm{X}-100$ to a final protein concentration of $0.1-0.2 \mathrm{mg} / \mathrm{ml}$. The receptor was incubated for $30 \mathrm{~min}$ at $4^{\circ} \mathrm{C}$ in the presence of $100 \mathrm{nM}$ insulin after which $\left.100 \mu \mathrm{M} \gamma{ }^{32} \mathrm{P}\right] \mathrm{ATP}(140 \mu \mathrm{Ci} / \mathrm{ml})$ and $5 \mathrm{mM} \mathrm{Mn}^{2+}$ were added. Phosphorylation of the $1142-1153$ peptide with $\gamma\left[{ }^{32} \mathrm{P}\right] A T P$ was carried out overnight at $4^{\circ} \mathrm{C}$ to give a specific activity of $\sim 7,000$ $\mathrm{cpm} / \mathrm{pmol}$ of peptide.

Tissue extraction. All tissue extractions were performed at $4^{\circ} \mathrm{C}$. Rats were killed by cervical dislocation, and livers were rapidly removed. Livers were homogenized in $25 \mathrm{mM}$ Hepes, $\mathrm{pH} 7.0,1 \mathrm{mM}$ EDTA, $1 \mathrm{mM}$ DTT PMSF $(0.0025 \% \mathrm{wt} / \mathrm{vol})$ and aprotinin $(1 \mathrm{U} / \mathrm{ml})$ for $30 \mathrm{~s}$ using a Polytron (Brinkmann Instrument Co., Westbury, NY), followed by 15 strokes of loose-fitting Dounce homogenizer. Homogenates were centrifuged at $600 \mathrm{~g}$ for $10 \mathrm{~min}$ and the supernatants were centrifuged at $10,000 \mathrm{~g}$ for $20 \mathrm{~min}$ to remove mitochondria. The postmitochondrial supernatant was then centrifuged $45 \mathrm{~min}$ at $100,000 \mathrm{~g}$. The final supernatant was designated the cytosolic fraction, and the pellet was designated the particulate fraction. The particulate fraction was solubilized before assay by stirring at $4^{\circ} \mathrm{C}$ for $45 \mathrm{~min}$ in $25 \mathrm{mM}$ Hepes, pH 7.0, 2.5\% PMSF (0.0025\% wt/vol) and $1 \%$ Triton X-100. All preparations were stored at $-70^{\circ} \mathrm{C}$ before use. Samples were assayed directly or after gel filtration chromatography on Sephadex G-75 superfine $(1.6 \times 72 \mathrm{~cm})$ eluted with $25 \mathrm{mM}$ Hepes, pH 7.0, $100 \mathrm{mM}$ $\mathrm{NaCl}, 1 \mathrm{mM}$ EDTA, $1 \mathrm{mM}$ DTT, and PMSF (0.0025\% wt/vol).

${ }^{125}$ I-insulin binding to solubilized insulin receptors. Aliquots $(2 \mu \mathrm{g}$ protein) of WGA eluate were incubated with ${ }^{125} \mathrm{I}$-insulin $(0.1 \mathrm{ng} / \mathrm{ml}$, $2,000 \mathrm{Ci} / \mathrm{mmol}$ ), in the absence or presence of $1 \mu \mathrm{mol}$ unlabeled insulin at $4^{\circ} \mathrm{C}$ for $10 \mathrm{~h}$ in a medium of $150 \mathrm{mM} \mathrm{NaCl}$ and $50 \mathrm{mM}$ Hepes at pH 7.4 containing $0.1 \%$ bovine serum albumin. Separation of free from receptor-bound insulin was then performed by the polyethylene glycol method (38) using bovine gamma globulin as carrier protein.

Phosphorylation with solubilized receptors. Phosphorylation was studied with slight modification of the method of Kasuga et al. (39). Solubilized, lectin-purified insulin receptor $(2.5 \mu \mathrm{g}$ protein for the control group, equal amount of binding from STZ-treated rats, $8 \mathrm{~d}$ duration) was diluted to $50 \mu \mathrm{l}$, in a final concentration of $50 \mathrm{mM}$ Hepes (pH 7.4), $5 \mathrm{mM} \mathrm{Mn}^{2+}, 0.1 \%$ Triton X-100, with or without insulin $(1,000 \mathrm{ng} / \mathrm{ml})$. These mixtures were incubated at $22^{\circ} \mathrm{C}$ for 10 $\mathrm{min}$. The phosphorylation reaction was initiated by adding $\gamma\left[{ }^{32} \mathrm{P}\right] \mathrm{ATP}$ and terminated by adding fivefold concentrated Laemmli sample buffer. The mixture was heated immediately in boiling water for $3 \mathrm{~min}$. The proteins were separated in $7.5 \%$ polyacrylamide gel electrophoresis according to Laemmli (40). The gels were stained with Coomassie blue in $50 \%$ TCA, destained in $7 \%$ acetic acid, dried, and subjected to autoradiography. The incorporation of ${ }^{32} \mathrm{P}$ into the $95-\mathrm{kD} \beta$-subunit band was quantified by scanning densitometry.

Dephosphorylation of the $95-k D$ protein by cytosolic fractions from livers of control and STZ-treated rats. Aliquots of WGA eluate ( $100 \mu \mathrm{g}$ protein) in $200 \mu \mathrm{l}$ of $50 \mathrm{mM}$ Hepes buffer, pH 7.4, $5 \mathrm{mM} \mathrm{Mn}^{2+}, 0.1 \%$ Triton X-100 were incubated with insulin $(1 \mu \mathrm{M})$ for $1 \mathrm{~h}$ at $4^{\circ} \mathrm{C}$. Phosphorylation was initiated by adding $25 \mu \mathrm{M}$ ATP containing 200 $\mu \mathrm{Ci} \gamma\left[{ }^{32} \mathrm{P}\right] \mathrm{ATP}$ for $1 \mathrm{~h}$ at $4^{\circ} \mathrm{C}$. The reaction mixture was desalted by gel filtration chromatography using Bio-rad P-6. The dephosphorylation of the partially purified insulin receptor was assayed in the presence of $2 \mathrm{mM}$ EDTA, $1 \mathrm{mM}$ DTT, PMSF ( $0.0025 \% \mathrm{wt} / \mathrm{vol}), 0.5 \mathrm{mM}$ benzamidine, $25 \mu \mathrm{g} / \mathrm{ml}$ leupeptin, and $5 \mu \mathrm{g} / \mathrm{ml}$ aprotinin. After incubation at $30^{\circ} \mathrm{C}$ with buffer or with equal amounts of tissue extract from control or STZ-treated rats for the indicated periods of time, the reaction was stopped by boiling in Laemmli buffer containing $100 \mathrm{mM}$ DTT and proteins were separated by $7.5 \%$ polyacrylamide gel electrophoresis (40). The gel was stained and were subjected to autoradiography. The incorporation of ${ }^{32} \mathrm{P}$ into the $95-\mathrm{kD} \beta$-subunit band was quantified by scanning densitometry.

PTPase assay. The mixture of WGA-purified insulin receptor and phosphorylated peptide substrate was heated at $55^{\circ} \mathrm{C}$ for $10 \mathrm{~min}$ to inactivate any kinase or phosphatase activity in the mixture (36). Phosphotyrosine phosphatase activity in tissue extracts was assayed by incubation with $40 \mu \mathrm{l}$ of tissue extract diluted in $25 \mathrm{mM}$ Hepes, $\mathrm{pH}$ 7.0, $1 \mathrm{mM}$ EDTA, $1 \mathrm{mM}$ DTT and $0.0025 \% \mathrm{wt} / \mathrm{vol}$ PMSF with $10 \mu \mathrm{l}$ substrate mixture. The dephosphorylation reaction was carried out at $30^{\circ} \mathrm{C}$ and was terminated by the addition of $50 \mu$ lice-cold 5\% TCA and $20 \mu \mathrm{l} 1 \% \mathrm{BSA}$. After incubation at $0^{\circ} \mathrm{C}$ and centrifugation to remove precipitated proteins, the supernatant containing the soluble peptide was applied to phosphocellulose paper and subjected to four 15-min washes in $75 \mathrm{mM}$ phosphoric acid. The radioactivity remaining in the paper-bound peptide was determined by Cherenkov radiation (37). The activity of the enzyme sample was calculated by comparing the dephosphorylation of the peptide substrate by tissue extracts to that observed with buffer alone. $1 \mathrm{U}$ of PTPase activity was defined as the amount of enzyme releasing $1 \mathrm{pmol}\left[{ }^{32} \mathrm{P}\right] \mathrm{Pi}$ per min. The reaction was linear with respect to time (Fig. 1), substrate concentration and enzyme concentration up to $50 \%$ of substrate hydrolysis. In subsequent experiments, the dephosphorylation assay was conducted for $10 \mathrm{~min}$.

Analytic methods. Blood glucose levels were determined using ACCU-CHEC II (Boehringer Mannheim Diagnostics Division, Indianapolis, IN). Plasma immunoreactive insulin concentration was determined by the polyethylene glycol method using rat insulin as a standard (38). Protein concentrations were determined by the methods of Coomassie and Bradford (41) using IgG immunoglobulin as a standard.

Statistics. Data were presented as mean \pm SEM. The Student's $t$ test was used to compare two groups, and analysis of variance was used to compare more than two groups.

\section{Results}

Physiology of the diabetic animal. Data concerning blood glucose, body weight, and liver weight in STZ- and BB-diabetic rats and the effects of vanadate and insulin treatment are summarized in Tables I and II. Liver weights were lower after $2 \mathrm{~d}$ of STZ diabetes, but the differences were not statistically significant. Both body weights and liver weights were significantly lower after $30 \mathrm{~d}$ of STZ diabetes and in the BB-diabetic rats as compared to matched control rats. Blood glucose levels were 


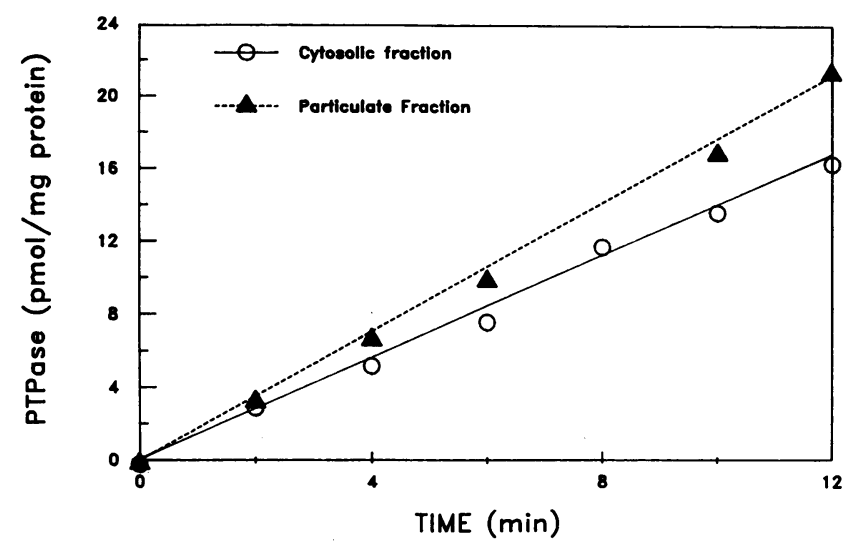

Figure 1. Time course of PTPase activity. PTPase activity was assayed in cytosolic and in particulate fractions. Peptide substrate (2 $\mathrm{mM}$ ) was incubated overnight with WGA-purified insulin receptor from rat liver (final protein concentration $0.1-0.2 \mathrm{mg} / \mathrm{ml}$ ) in the presence of insulin $100 \mathrm{mM}, 5 \mathrm{mM} \mathrm{Mn}^{2+}$ and $100 \mu \mathrm{M} \gamma\left[^{32} \mathrm{P}\right] \mathrm{ATP}$ at $4^{\circ} \mathrm{C}$ in $50 \mathrm{mM}$ Hepes and $0.1 \%$ Triton X-100. The mixture was heated to $55^{\circ}$ for 10 min to inactivate the receptor kinase and any phosphatases (23). $40 \mu$ l of tissue extract diluted in $25 \mathrm{mM}$ Hepes pH 7.0, 1 $\mathrm{mM}$ EDTA, $1 \mathrm{mM}$ DTT and $0.0025 \% \mathrm{wt} / \mathrm{vol}$ PMSF, were incubated with $10 \mu \mathrm{l}$ of the substrate mixture. The dephosphorylation reaction was carried out at $30^{\circ} \mathrm{C}$ and was terminated by the addition of $50 \mu \mathrm{l}$ $5 \% \mathrm{TCA}$ and $20 \mu \mathrm{l} \mathrm{BSA} 1 \% \mathrm{wt} / \mathrm{vol}$ at the indicated times. ${ }^{32} \mathrm{P}$-labeled peptide was collected by filtration in phosphocellulose paper and incorporation of phosphate into the substrate was determined by Cerenkov radiation (37). The enzyme activity was calculated by comparing ${ }^{32} \mathrm{P}$ content after incubation with the tissue extracts with the ${ }^{32} \mathrm{P}$ content after incubation with the buffer alone.

markedly increased, while the ratio of serum insulin concentration to blood glucose levels was markedly decreased in both models of insulin-deficient diabetes (Table I). $3 \mathrm{~d}$ of treatment with vanadate or insulin normalized blood glucose levels, but liver weight and body weight remained decreased in the vanadate-treated STZ-diabetic rats (Table I).

Effect of STZ diabetes on receptor autophosphorylation. An autoradiogram showing in vitro phosphorylation of WGA purified extracts derived from the livers of STZ-diabetic rats $(8 \mathrm{~d}$ duration) and control rats is presented in Fig. $2 A$ and quantified in $B$. For each group, both basal and insulin stimulated incorporation of ${ }^{32} \mathrm{P}$ into the $95-\mathrm{kD} \beta$-subunit of the insulin receptor was examined. Insulin stimulation of solubilized insulin receptor autophosphorylation was decreased to $\sim 55 \%$ of the control values, similar to previous studies from our laboratory and others $(19,20)$.

Effect of diabetes on tyrosine PTPase activity in STZ-diabetic rats. Cytosolic fractions from livers of STZ-diabetic rats and their matched control were assayed for specific PTPase activity in the presence of EDTA $(1 \mathrm{mM})$ and with or without $0.2 \mathrm{mM} \mathrm{ZnCl}$. The results in all assays are expressed as zincinhibitable PTPase activity per milligram protein. $2 \mathrm{~d}$ after induction of STZ diabetes, the PTPase activity in liver cytosol increased from $1.3 \pm 0.3$ to $2.3 \pm 0.2 \mathrm{U} / \mathrm{mg}$ protein, a $180 \%$ increase above control values $(P<0.02)$, and after $30 \mathrm{~d}$ of STZ diabetes, the cytosolic PTPase increased from $1.2 \pm 0.5$ to 2.0 $\pm 0.2 \mathrm{U} / \mathrm{mg}$ protein (Fig. 3). To determine if the increase in activity was associated with a new species of PTPase, cytosolic samples from 30-d STZ-diabetic rats and their controls were analyzed by gel-filtration chromatography on G-75 Sephadex. PTPase activity from both extracts eluted as a single peak of activity at $M_{\mathrm{r}}=20-25 \mathrm{kD}$ (data not shown). When the column fractions were assayed, peak activity derived from diabetic sample was 4.9-fold higher than control (14.1 vs. $2.9 \mathrm{U} / \mathrm{mg}$ protein).

To determine if this increase in PTPase activity could affect insulin receptor autophosphorylation in STZ-diabetic rats, we assayed PTPase activity directly using the WGA-purified insulin receptors which had undergone autophosphorylation in vitro. When equal amounts of cytosolic protein were used from control and STZ-diabetic rats (8 d duration), the preparation from diabetic rats dephosphorylated the insulin receptor $\beta$-subunit at about twice the rate of the control (Fig. 4, $A$ and $B$ ).

Particulate fractions obtained from STZ diabetic rats and controls were also assayed for tyrosyl-specific PTPase activity after solubilization in $1 \%$ Triton X-100 (Fig. 5). PTPase activity in the particulate fraction toward the peptide substrate increased from $2.2 \pm 0.2$ to $2.9 \pm 0.2 \mathrm{U} / \mathrm{mg}$ protein after $2 \mathrm{~d}$ of diabetes. However, after $30 \mathrm{~d}$ of diabetes, PTPase activity as-

Table I. Characteristics of Diabetic Rats

\begin{tabular}{|c|c|c|c|c|c|c|}
\hline Groups & Duration of diabetes & Body weight & Liver weight & Blood glucose & Insulin & Insulin/glucose ratio \\
\hline & $d$ & $g$ & $g$ & $m g / d l$ & $\mu U / m l$ & \\
\hline \multicolumn{7}{|c|}{ STZ-diabetic rats } \\
\hline Control & - & $199 \pm 3$ & $9.1 \pm 0.2$ & $90 \pm 5$ & $21.2 \pm 0.2$ & $0.187 \pm 0.014$ \\
\hline Diabetic & 2 & $183 \pm 2 *$ & $8.4 \pm 0.5$ & $347 \pm 26^{\ddagger}$ & $18.0 \pm 0.6$ & $0.054 \pm 0.005^{\S}$ \\
\hline \multicolumn{7}{|c|}{ STZ-diabetic rats } \\
\hline Control & - & $357 \pm 15$ & $11.2 \pm 0.2$ & $130 \pm 8$ & ND & ND \\
\hline Diabetic & 30 & $187 \pm 45^{*}$ & $8.3 \pm 0.1$ & $518 \pm 62^{*}$ & & \\
\hline \multicolumn{7}{|l|}{$\mathrm{BB}$ rats } \\
\hline Control & - & $387 \pm 27$ & $10.6 \pm 16$ & $113 \pm 23$ & $18.8 \pm 0.4$ & $0.150 \pm 0.013^{\S}$ \\
\hline Diabetic & $34 \pm 16$ & $327 \pm 17^{\prime \prime}$ & $9.9 \pm 0.7$ & $333 \pm 48^{\ddagger}$ & $22.7 \pm 0.4$ & $0.050 \pm 0.009^{\S}$ \\
\hline
\end{tabular}

\footnotetext{
The results represent the mean \pm SEM of five rats in each group assay in duplicate in three separate experiments. ${ }^{*} P<0.005$ compared to
} control. ${ }^{\ddagger} P<0.0005$ compared to control. ${ }^{\S} P<0.02$ compared to control. " $P<0.01$ compared to control. 
Table II. Effects of Vanadate and Insulin Treatment on STZ-induced Diabetic Rats

\begin{tabular}{lcc}
\hline Treatment & Blood glucose & Liver weight \\
\hline & $m g / d l$ & $g$ \\
Control & & \\
None & $72 \pm 4$ & $12 \pm 0.2$ \\
Vanadate & $66 \pm 3$ & $11.1 \pm 0.6$ \\
Diabetic rats & & \\
None & $393 \pm 53^{*}$ & $10.3 \pm 0.6^{\ddagger}$ \\
Vanadate & $114 \pm 48$ & $9.6 \pm 0.2^{\ddagger}$ \\
Insulin & $65 \pm 12$ & $12.0 \pm 0.5$ \\
\hline
\end{tabular}

${ }^{*} P<0.0005$

$\ddagger P<0.05$.

The number of rats in each group was five. The results represent the mean \pm SEM of five rats in each group assay in duplicate in three experiments. The duration of the STZ diabetes was $8 \mathrm{~d}$.

sociated with the particulate fraction decreased to $2.8 \pm 0.4$ compared to $4.1 \pm 0.7 \mathrm{U} / \mathrm{mg}$ protein of the control values. While the difference in control levels of PTPase activity reflects differences in the length of sample storage, the changes in particulate PTPase activity relative to control after $30 \mathrm{~d}$ are significant $(P<0.02)$.

Changes of PTPase activity in BB-diabetic rats. PTPase activity was assayed in BB rats after $30 \mathrm{~d}$ duration of diabetes (Fig. 6). The cytosolic PTPase activity increased to $1.86 \pm 0.18$ $\mathrm{U} / \mathrm{mg}$ protein in the $\mathrm{BB}$ rats as compared to $0.82 \pm 0.14 \mathrm{U} / \mathrm{mg}$ protein in matched controls $(P<0.01)$. The PTPase activity of the particulate fraction decreased by $\sim 30 \%$ (from $7.2 \pm 1.7$ to $5.4 \pm 1.3 \mathrm{U} / \mathrm{mg}$ protein $[0.05<P]$ ), a finding similar to the result seen after $30 \mathrm{~d}$ of STZ diabetes.

Effect of treatment on PTPase activity. We examined the effects of two types of treatment on PTPase activity in the liver of STZ-diabetic rats. $5 \mathrm{~d}$ after induction of STZ diabetes rats were treated with insulin ( $14 \mathrm{U} /$ rat per $\mathrm{d}$, two-thirds of the dose in the morning and one-third in the afternoon) or with vanadate $(0.6 \mathrm{mg} / \mathrm{ml})$ included in the drinking water. In the vanadate-treated rats and their controls $75 \mathrm{mM} \mathrm{NaCl}$ was included in the drinking water to reduce vanadate toxicity, as previously described $(30,31)$. In these experiments, specific PTPase activity almost doubled in the particulate fraction from the untreated STZ-diabetic rats $[3.3 \pm 0.3 \mathrm{U} / \mathrm{mg}$ protein as compared to controls $1.8 \pm 0.25 \mathrm{U} / \mathrm{mg}$ protein, $(P<0.05)$ ], (Fig. 7). After $3 \mathrm{~d}$ of treatment with vanadate or insulin, PTPase activity in STZ rats was reduced to very low levels $(0.2-0.4 \mathrm{U} / \mathrm{mg})$. A similar decrease was observed in control rats treated with vanadate. Neither insulin nor vanadate had any effect on cytosolic PTPase activity (data not shown).

\section{Discussion}

Insulin-deficient diabetes in STZ-induced or BB diabetic rats is associated with a blunted response to insulin stimulation of glucose transport, glucose oxidation, and lipogenesis in several tissues including skeletal and heart muscle (42), adipose tissue (44-46), and liver $(47,48)$, despite increased insulin binding $(44,45,48)$. The decrease in insulin action is associated with decreases in both receptor autophosphorylation and activity of
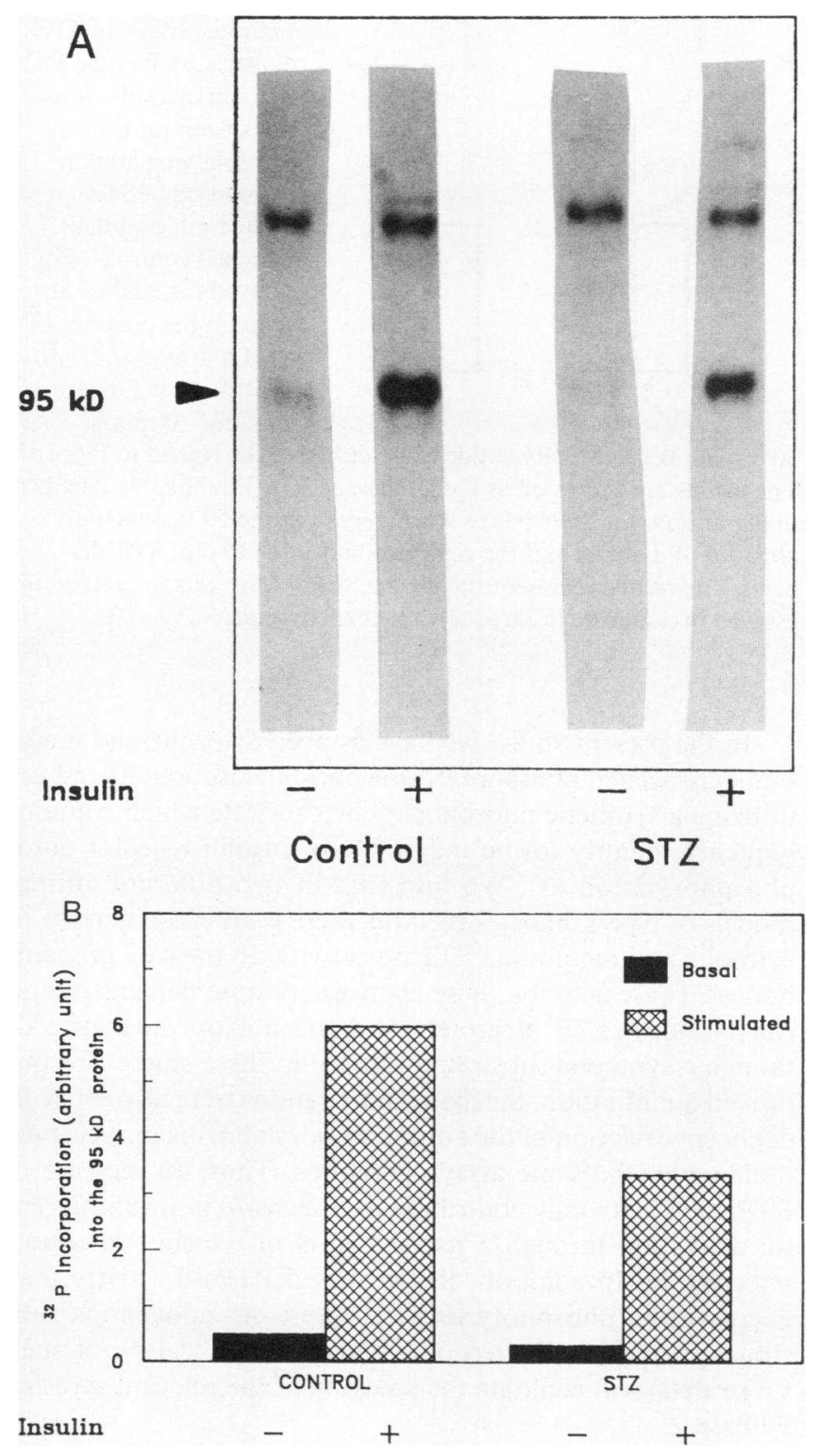

Figure 2. (A) Autoradiogram showing phosphorylation of $95 \mathrm{kD} \beta$ subunit of insulin receptor and the $170 \mathrm{kD}$ EGF receptor in liver from streptozotocin diabetic and control rats. Aliquots of WGA eluate in $50 \mu \mathrm{l}$ of buffer were incubated with or without insulin (1 $\mu \mathrm{g} / \mathrm{ml}$ ) for $10 \mathrm{~min}$ at $22^{\circ} \mathrm{C}$. The phosphorylation reaction was initiated by adding $20 \mu \mathrm{M}$ ATP and $20 \mu \mathrm{Ci} /$ tube of $\gamma\left[{ }^{32} \mathrm{P}\right] \mathrm{ATP}$. After stopping the reaction, the mixture was reduced with DTT, separated by SDS-PAGE and subjected to autoradiography. In each pair, the left lane is without insulin and the right lane is insulin stimulated. (B) ${ }^{32} \mathrm{P}$ incorporation into the $95-\mathrm{kD}$ protein, control and $\mathrm{STZ}$ rat. These data were derived from $A$ by densitometry scanning and are represented in arbitrary units. In each pair, the open column is without insulin and the cross hatched column is from insulin-stimulated rats $(1 \mu \mathrm{M})$.

the receptor tyrosine kinase $(19,20)$. Although these alterations in the metabolic responses to insulin may result from a decrease in the intrinsic activity of the insulin receptor kinase, changes in the activity of enzymes responsible for phosphotyrosine dephosphorylation may also contribute to the blunting of insulin bioeffects. 


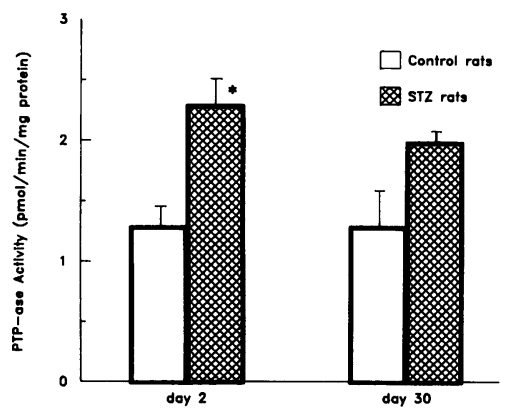

Figure 3. Effect of STZ diabetes on PTPase activity in cytosolic fractions from rat liver. A cytosolic preparation from livers of STZtreated rats and their matched controls were assayed for PTPase activity in the presence of EDTA $1 \mathrm{mM}$ and with or without $0.2 \mathrm{mM}$ $\mathrm{Zn}^{2+}$ for $10 \mathrm{~min}$ at $30^{\circ} \mathrm{C}$ with $0.12 \mu \mathrm{M}^{32} \mathrm{P}$ peptide as described in the legend to Fig. 1 . The results are expressed as the PTPase activity inhibited by zinc per milligram protein. The left two bars represent the PTPase activity after $2 \mathrm{~d}$ of diabetes and the right two bars after $30 \mathrm{~d}$ of STZ diabetes. The results represent the mean \pm SEM of five rats in each group assayed in duplicate in three separate experiments. $* P<0.02$.

In the present study, we have assayed cytosolic and membrane-associated phosphotyrosine phosphatase activity in liver utilizing a synthetic phosphopeptide substrate which contains sequence identify to the major site of insulin receptor autophosphorylation (3). We find that in two different animal models of type I diabetes mellitus there is an early increase in cytosolic and membrane PTPase activity. In the case of membrane PTPase activity, these changes are time dependent and can be affected by treatment with insulin or vanadate. Although a synthetic substrate was used in these studies for improved quantitation, the tissue preparations were also active in dephosphorylation of the autophosphorylated insulin receptor itself under the same assay conditions. Thus, an increase in PTPase activity may contribute to a decrease in insulin receptor activation through a reduced level of tyrosine autophosphorylation. In addition, the increased PTPase activity may decrease the phosphotyrosine content of endogenous substrates of the insulin receptor kinase. Identification of such substrate(s) will facilitate the studying of the relevant tyrosine PTPase.

Although the exact relationship between the cytosolic and membrane PTPase activities is uncertain, some differences were noted when we compared diabetes-related changes in the two compartments. First, after $30 \mathrm{~d}$ of diabetes we observed an increase in the cytosolic PTPase activity both in the STZ and BB diabetic rats, whereas the PTPase activity associated with the particulate fraction was slightly decreased in these animals at the same time. In addition, we observed that $3 \mathrm{~d}$ of treatment of STZ diabetic rat with insulin or vanadate markedly reduced the PTPase activity in the particulate fraction, but had no effect on the PTPase activity of the cytosolic fraction.

Previous work (17) has suggested that in the kidney, a membrane-bound PTPase can be distinguished from its cytosolic counterpart based on differential elution from DEAESepharose, thermal lability and sensitivity to dodecyl sulfate. On the other hand, Tonks et al. (15) reported that little difference could be detected between the cytosolic and particulate forms of the enzyme purified from human placenta. Since our data indicate that PTPase activity of the two fractions are affected differently by type I diabetes and its treatment, more detailed studies of the relationship of these two forms of the enzymes are warranted.
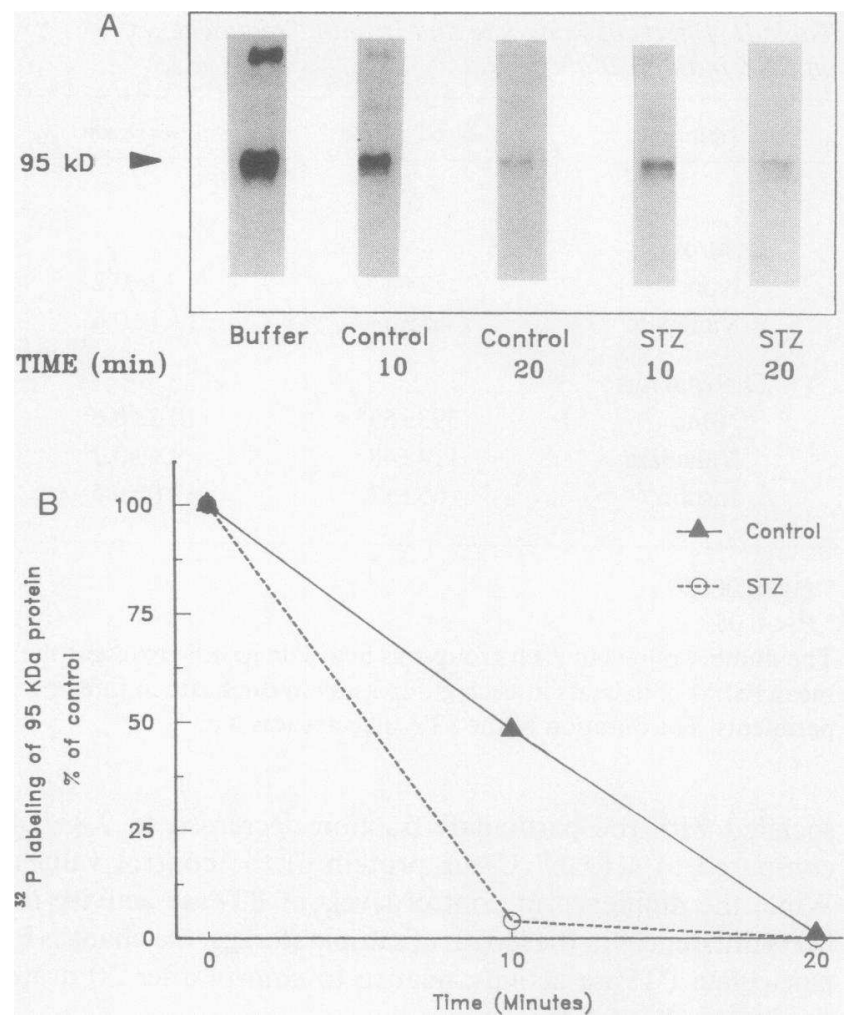

Figure 4. (A) Dephosphorylation of a 95-kD $\beta$-subunit of the insulin receptor by cytosolic fractions from livers of control and STZ-treated rats. Aliquots of WGA eluate ( $100 \mu \mathrm{g})$ from STZ-treated (8 d duration) and control rats were incubated with insulin $(1 \mu \mathrm{M})$ for $1 \mathrm{~h}$ in a volume of $200 \mu \mathrm{l}$. The phosphorylation reaction was initiated by adding $25 \mu \mathrm{M}$ ATP containing $200 \mu \mathrm{Ci} \gamma\left[{ }^{32} \mathrm{P}\right] \mathrm{ATP}$ and incubated for $1 \mathrm{~h}$ at $4^{\circ} \mathrm{C}$. The reaction mixture was desalted using a Bio-rad P-6 column. The dephosphorylation of the partially purified insulin receptor was assayed in the presence of $2 \mathrm{mM}$ EDTA, $1 \mathrm{mM}$ DTT, and protease inhibitors: PMSF $(0.0025 \% \mathrm{wt} / \mathrm{vol}), 0.5 \mathrm{mM}$ benzamidine, $25 \mu \mathrm{g} / \mathrm{ml}$ leupeptin and $5 \mu \mathrm{g} / \mathrm{ml}$ aprotinin. After incubation at $30^{\circ} \mathrm{C}$ for the indicated periods of time the reaction was stopped by boiling for $3 \mathrm{~min}$ in Laemmli buffer containing $100 \mathrm{mM}$ DTT. Proteins were separated by $7.5 \%$ SDS-PAGE and subjected to autoradiography. The left lane is the WGA eluate after a 40-min incubation with buffer alone. In the other lanes, the WGA eluate was incubated with equal amounts of cytosolic protein from control (lanes 3,4 ) and STZ-treated rats $(65 \mathrm{mg} / \mathrm{kg}, 8 \mathrm{~d}$ duration, lanes 5,6$)$. Lanes 3 and 5 represent $10 \mathrm{~min}$ of reaction; lanes 4 and 6 represent $20 \mathrm{~min}$ of reaction. $(B)$ The data were quantified by densitometric scanning of $A ;{ }^{32} \mathrm{P}$ labeling of the $95-\mathrm{kD}$ protein is expressed as percentage of the value after incubation with the buffer alone. The solid line represents dephosphorylation using cytosolic fraction from control rats and the dashed line represents incubation with cytosolic fraction from $S T Z$ rats.

The specific factors regulating PTPase activity and their mechanisms of action are unknown. The insulin receptor is an insulin-activated tyrosine-specific protein kinase (2-5). Insulin may stimulate a cascade of tyrosine and serine phosphorylations that ultimately affect the phosphorylation state of PTPases, similar to that observed for other insulin regulated enzymes (reviewed in 1). Alternatively, a hormonally stimulated translocation of the PTPase might provide a regulatory mechanism, in a manner analogous to the translocation of 


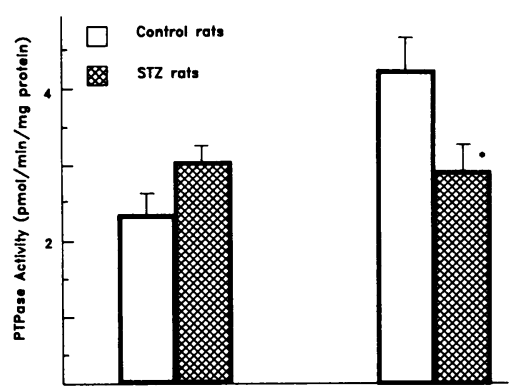

Day 2
Figure 5. Effect of STZ diabetes on PTPase activity in particulate fractions from rat liver. Particulate fractions from livers of STZ rats and their matched controls were prepared and solubilized in $1 \%$ Triton $\mathrm{X}-100$ as described in Methods. The extracts were assayed for PTPase activity and the results expressed as described in the legend to Fig. 2. The left two bars describe the PTPase in the particulate fraction activity after $2 \mathrm{~d}$ and the right two bars after $30 \mathrm{~d}$ of STZ-induced diabetes. The results represent the mean \pm SEM of five rats in each group assayed in duplicate in three separate experiments. $* P<0.02$.

protein kinase $C$ (49-51). An insulin stimulated redistribution of the Mg ATP-dependent multifunctional protein phosphatase activator has also been demonstrated in human platelets $(54,55)$. Change in the activation state of a PTPase inhibitor $(52,53)$ could provide a third possible mechanism. Protein inhibitors of serine phosphoprotein phosphatases have been well documented (reviewed in 1), and some preliminary studies suggest the presence of PTPase inhibitors as well (15).

The treatment of the STZ-diabetic rats either with insulin or with vanadate significantly decreases the membrane-associated PTPase activity. While any of the above mechanisms could potentially mediate the insulin effect, vanadate has been shown to be a strong inhibitor of PTPase activity at concentrations that do not inhibit phosphoserine and phosphothreonine phosphatases $(55,56)$. Some groups have found that vanadate also directly stimulates $\beta$-subunit tyrosine autophosphorylation and in vitro phosphotransferase activity of purified insulin receptors (34), but this has not been observed in all studies (33). Based on previous studies, treatment with vanadate at the concentrations used here should produce a vanadate serum concentration of $\sim 7 \mu \mathrm{M}$ (31). This vanadate concentration will inhibit the PTPase activity in both of the cytosol and particulate fractions of the liver preparation almost completely in vitro (data not shown). This concentration

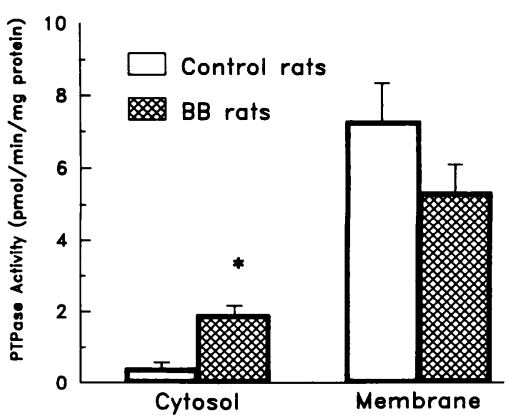

Figure 6. PTPase activity in livers of BB diabetic rats and their matched control. Cytosolic and Triton X-100 solubilized particulate fractions were prepared from rat liver as described in Methods. The extracts were assayed for PTPase activity as described in the legend to Fig. 2. The left two bars represent the PTPase activity in the cytosolic fraction and the right two bars in the particulate fraction of the BB rats and their controls. The results represent mean \pm SEM of five rats in each group assayed in duplicate in three separate experiments. $* P<0.02$.

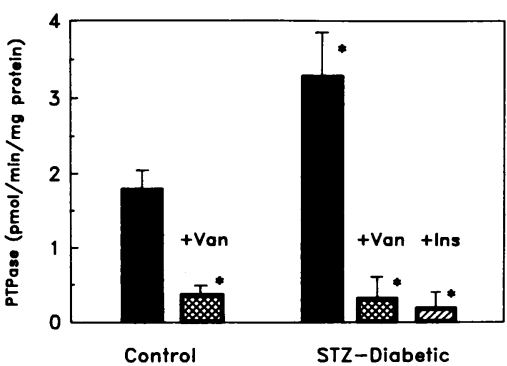

Figure 7. Effects of treatment on PTPase activity in particulate fractions from rats liver. $5 \mathrm{~d}$ after induction of STZ diabetes, rats were treated with insulin (14 $U$ per day per rat, $2 / 3$ of the dose in the morning and $1 / 3$ at 5 p.m.), vanadate $(0.6 \mathrm{mg} / \mathrm{ml}$ with 75 $\mathrm{mM} \mathrm{NaCl}$ ) or with drinking water with $75 \mathrm{mM} \mathrm{NaCl}$ alone. PTPase activity from the rat livers was assayed as described in Fig. 2 . The left panel describes the PTPase activity in the particulate fractions derived from control rats and the right panel the particulate fraction derived from STZ-diabetic rats with and without treatment. The results represent mean $\pm S E M$ of five rats in each group assayed in duplicate in three separate experiments. $* P<0.05$.

is significantly lower than the vanadate concentration reportedly effective in stimulating insulin receptor autophosphorylation in vitro (34). This suggests that the normalization of serum glucose levels by vanadate in STZ-diabetic rats is more likely due to its inhibitory effects on PTPase rather than a direct stimulation of insulin receptor kinase activity. Thus, the modulation of PTPase activity with vanadate may prove to be an additional tool in the treatment of insulin resistance states.

\section{Acknowledgments}

The authors would like to thank Terri-Lyn Bellman and Maria Iocco for excellent secretarial assistance, Dr. J. Warram for helping in statistical analysis, and Dr. Y. Shechter for many useful discussions.

This work was supported in part by National Institutes of Health grants DK-33201 to Dr. Kahn, National Research Service Award DK-08126 to Dr. Backer, the Joslin DERC (NIH DK-36836) and by grant 188182 from the Juvenile Diabetes Foundation.

\section{References}

1. Cohen, P. 1982. The role of protein phosphorylation in neural and hormonal control of cellular activity. Nature (Lond.). 296:613620.

2. White, M. F., and C. R. Kahn. 1986. The insulin receptor and tyrosine phosphorylation. In The Enzymes. P. D. Boyer and E. G. Krebs, editors. Academic Press, Inc., Orlando, FL. 248-285.

3. Ullrich, A., J. R. Bell, E. Y. Chen, R. Herrera, L. M. Petruzzelli, T. J. Dull, A. Gray, L. Coussens, Y. C. Liao, M. Tsubokawa, A. Mason, P. H. Seeburg, C. Grunfeld, O. M. Rosen, and J. Ramachandran. 1985. Human insulin receptor and its relationship to the tyrosine kinase family of oncogenes. Nature (Lond.). 313:756-761.

4. White, M. F., S. E. Shoelson, H. Keutmann, and C. R. Kahn. 1988. A cascade of tyrosine autophosphorylation in the $\beta$-subunit activates the phosphotransferase of the insulin receptor. J. Biol. Chem. 263:2969-2980.

5. Tornqvist, H. E., M. W. Pierce, A. R. Frackelton, R. A. Nemenoff, and J. Avruch. 1987. Indentification of insulin receptor tyrosine residues autophosphorylated in vitro. J. Biol. Chem. 262:1021210219.

6. Ellis, L., E. Clauser, D. O. Morgan, M. Edery, R. A. Roth, and W. J. Rutter. 1986. Replacement of insulin receptor tyrosine residues 1162 and 1163 compromises insulin-stimulated kinase activity and uptake of 2-deoxyglucose. Cell. 45:721-732. 
7. Morgan, D. O., and R. A. Roth. 1987. Acute insulin action requires insulin receptor kinase activity. Introduction of an inhibitory monoclonal antibody into mammalian cells block rapid effects of insulin. Proc. Natl. Acad. Sci. USA. 84:41-45.

8. Chou, C. K., T. J. Dull, D. S. Russell, R. Gherzi, D. Lebwhol, A. Ullrich, and O. Rosen. 1987. Human Insulin receptors mutated at the ATP-binding site lack protein tyrosine kinase activity and fail to mediate postreceptor effects of insulin. J. Biol. Chem. 262:1842-1846.

9. Brautigan, D. L., P. Borenstein, and B. Gallis. 1981. Phosphotyrosyl-protein Phosphatase-specific inhibition by $\mathrm{Zn}^{2+}$. J. Biol. Chem. 256:6519-6522.

10. Gallis, B., P. Bornstein, and D. L. Brautigan. 1981. Tyrosyl protein kinase and phosphatase activity in membrane vesicles from normal and Rous sarcoma virus-transformed rat cells. Proc. Natl. Acad. Sci. USA. 78:6689-6693.

11. Foulkes, J. G., R. F. Howard, and A. Ziemiecki. 1981. Detection of a novel mammalian protein phosphatase with activity for phosphotyrosine. FEBS (Fed. Eur. Biochem. Soc.) Lett. 130:197-200.

12. Okada, M., K. Owada, and H. Nakgawa. 1986. Phosphotyrosine protein phosphatase in rat brain. Biochem. J. 299:155-162.

13. Tung, H. Y. L., and L. J. Reed. 1987. Identification and purification of a cytosolic phosphotyrosyl protein phosphatase from bovine spleen. Anal. Biochem. 161:412-416.

14. Shriner, C. L., and D. L. Brautigan. 1984. Cytosolic protein phosphotyrosine phosphatases from rabbit kidney. J. Biol. Chem. 259:11383-11390.

15. Tonks, N. K., C. D. Diltz, and E. H. Fischer. 1988. Purification of the major protein-tyrosine-phosphatases of human placenta. J. Biol. Chem. 263:6722-6730.

16. Tonks, N. N., C. D. Diltz, and E. H. Fischer. 1988. Characterization of the major protein-tyrosine-phosphatases of human placenta. J. Biol. Chem. 263:6731-6737.

17. Rotenberg, S. A., and D. L. Brautigan. 1987. Membrane protein phosphotyrosine phosphatase in rabbit kidney. Biochem. $J$ 243:747-754.

18. Leis, J. F., A. F. Knowles, and N. O. Kaplan. 1985. Demonstration of separate phosphotyrosyl and phosphoseryl histone phosphatase activities in the plasma membrane of human astrocytoma. Arch. Biochem. Biophys. 239:320-326.

19. Kadowaki, T. M., M. Kasuga, Y. Akanuntoa, O. Ezaki, and F. Takaku. 1984. Decrease autophosphorylation of the insulin receptor kinase in streptozotocin diabetic rats. J. Biol. Chem. 22:14208-14216.

20. Burant, C. F., M. K. Treutelaar, and M. G. Buse. 1986. Diabetes-induced functional and structural changes in insulin receptors from rat skeletal muscle. J. Clin. Invest. 77:260-270.

21. Okamoto, M., M. F. White, R. Maron, and C. R. Kahn. 1986. Autophosphorylation and kinase activity of insulin receptor in diabetic rats. Am. J. Physiol. 251:E542-E550.

22. Amatruda, J. M., and A. M. Roncone. 1985. Normal hepatic insulin receptor autophosphorylation in non-ketotic diabetes mellitus. Biochem. Biophys. Res. Commun. 129:163-170.

23. Blackshear, P. J., R. A. Nemenoff, and J. Avruch. 1984. Characteristics of insulin and epidermal growth factor stimulation of receptor autophosphorylation in detergent extracts of rat liver and transplantable rat hepatomas. Endocrinology. 114:141-152.

24. Caro, J. F., O. Ittoop, W. J. Pories, D. Meelhein, E. G. Flickinger, F. Thomas, M. Jenquin, J. F. Silverman, P. G. Khazanie, and M. K. Sinha. 1986. Studies on the mechanism of insulin resistance in the liver from humans with non-insulin dependent diabetes. J. Clin. Invest. 78:249-258.

25. Freidenberg, G. R., R. R. Henry, H. H. Klein, D. R. Reichart, and J. M. Olefsky. 1987. Decreased kinase activity in insulin receptors from adipocytes of noninsulin-dependent diabetic subjects. J. Clin. Invest. 79:240-250.

26. Sinha, M. K., W. J. Pories, E. G. Flickinger, D. Meelheim, and J. F. Caro. 1987. Insulin receptor kinase activity of adipose tissue from morbidly obese humans with and without NIDDM. Diabetes. 36:620-625.

27. Takayama, S., C. R. Kahn, K. Kubo, and J. E. Foley. 1988. Alteration in insulin receptor autophosphorylation in insulin resistance: Correlation with altered sensitivity to glucose transport and antilipolysis to insulin. J. Clin. Endocrinol. Metab. 66:992-999.

28. Arner, P., T. Pollare, H. Lithell, and J. N. Livingston. 1987. Defective insulin receptor tyrosine kinase in human skeletal muscle in obesity and Type II (noninsulin-dependent) diabetes mellitus. Diabetologia. 30:437-440.

29. Shechter, Y., J. Meyerovitch, and S. Amir. 1988. The use of post binding agents in studying insulin action and its relation to experimental diabetes. Biochem. Pharmacol. 37:1891-1896.

30. Heyliger, C. E., G. A. Tahiliani, and T. H. McNeill. 1985. Effect of vanadate on elevated blood glucose and depressed cardiac performance of diabetic rats. Science (Wash. DC). 227:1474-1476.

31. Meyerovitch, J., Z. Farfel, J. Sack, and Y. Shechter. 1987. Oral administration of vanadate normalizes blood glucose levels in streptozotocin-treated rats. J. Biol. Chem. 262:6658-6662.

32. Chernoff, J., and H. C. Li. 1985. A major phosphotyrosyl-protein phosphatase from bovine-heart is associated with a low molecular weight acid phosphatase. Arch. Biochem. Biophys. 240:135-145.

33. Machicao, F., T. Urumow, and O. H. Wieland. 1983. Evidence for phosphorylation of actin by the insulin receptor associated protein kinase from human placenta. FEBS (Fed. Eur. Biochem. Soc.) Lett. 163:76-80.

34. Tamura, S., T. A. Brown, J. H. Whipple, Y. F. Yamaguchi, R. E. Dubler, M. Chelany, and J. Larner. 1984. A novel mechanism for the insulin-like effect of vanadate on glycogen synthase in rat adipocytes. J. Biol. Chem. 259:6650-6658.

35. Sparks, J. W., and D. L. Brautigan. 1985. Specificity of protein phosphotyrosine phosphatase. Comparison with mammaline alkaline phosphatase using polypeptide substrates. J. Biol. Chem. 260:20422045

36. Zick, Y., J. Whittaker, and J. Roth. 1982. Insulin stimulated phosphorylation of its own receptor. J. Biol. Chem. 258:3431-3434.

37. Glass, D. B., R. A. Masaracchia, J. R. Feramisco, and B. E. Kemp. 1978. Isolation of phosphorylated peptides and proteins on ion exchange paper. Anal. Biochem. 87:566-575.

38. Desbuquois, B., and G. D. Aurbach. 1971. Use of polyethylene glycol to separate free and antibody-bond peptide hormones in radio immunoassays. J. Clin. Endocrinol. 33:732-738.

39. Kasuga, M., M. F. White, and C. R. Kahn. 1984. Phosphorylation of the insulin receptor in cultured hepatoma cells and in solubilized system. Methods Enzymol. 109:609-621.

40. Laemmli, U. R. 1970. Cleavage of structural proteins during the assembly of the head of bacteriophage T4. Nature (Lond.). 227:680-685.

41. Bradford, M. M. 1976. A rapid and sensitive method for the quantitation of microgram quantities of protein utilizing the principle of protein dye binding. Anal. Biochem. 72:248-254.

42. Kipnis, D. M., and C. F. Cori. 1959. Studies of tissue permeability. $\mathrm{V}$. The penetration and phosphorylation of 2-deoxyglucose in the rat diaphragm. J. Biol. Chem. 234:171-177.

43. Morgan, H. E., E. Cadenas, D. M. Regen, and C. R. Park. 1961. Regulation of glucose uptake in muscle. II. Rate limiting steps and effects of insulin and anoxia in heart muscle from diabetic rats. J. Biol. Chem. 236:262-268.

44. Kasuga, M., Y. Akanuma, Y. Iwamoto, and K. Kosaka. 1978. Insulin binding and glucose metabolism in adipocytes from streptozotocin-diabetic rats. Am. J. Physiol. 235:E175-E182.

45. Kobayashi, M., and J. M. Olefsky. 1979. Effects of streptozotocin-induced diabetes on insulin binding, glucose transport, and intracellular glucose metabolism in isolated rat adipocytes. Diabetes. 28:87-95.

46. Kaenieki, E., P. J. Hissin, I. A. Simpson, L. B. Salans, and S. W. Cushmann. 1981. A possible mechanism of insulin resistance in the rat 
adipose cell in streptozotocin-induced diabetes mellitus. J. Clin. Invest. 68:811-814.

47. Haft, D. E. 1968. Studies of the metabolism of livers of normal and alloxan-diabetic rats perfused with insulin. Diabetes. 17:244-250.

48. LeMarchand, Y., E. G. Loten, F. Assimacopoulos-Jeannet, M. E. Forgue, P. Freychet, and B. Jeanrenaud. 1976. Effects of fasting and streptozotocin on the obese-hyperglycemic (ob/ob) mouse. Diabetes. 26:582-590.

49. Johhansen, J. W., and T. S. Ingebritsen. 1986. Phosphorylation and inactivation of protein phosphatase 1 by pp60 ${ }^{\mathrm{v}-\mathrm{src}}$. Proc. Natl. Acad. Sci. USA. 83:207-211.

50. Graeme, R. G., J. Gordon, L. Walker, R. H. Michell, and G. Brown. 1986. Redistribution of protein kinase $C$ during mitogenesis of human B lymphocytes. Biochem. Biophys. Res. Commun. 135:146153.

51. Cooper, D. R., T. S. Konda, M. L. Standaert, J. S. Davis, R. J. Pollet, and R. V. Farese. 1987. Insulin increases membrane and cytosolic protein kinase $\mathrm{C}$ activity in $\mathrm{BC}_{3} \mathrm{H}-1$ myocytes. J. Biol. Chem. 262:3633-3639.
52. Lee, T. S., L. C. MacGregor, S. J. Fluharty, and G. L. King. 1989. Differential regulation of protein kinase $\mathrm{C}$ and (Na,K)-ATPase activities by elevated glucose level in retinal capillary endothelial cells. J. Clin. Invest. 83:90-94.

53. Yang, S. D., J. S. Yu, J. S. Liu, T. C. Tzen, and J. K. Wang. 1987. The Type I protein phosphatase activating factor $\mathrm{Fa}$ is a membrane associated protein kinase in brain, liver, heart and muscles. Biochem. Biophys. Res. Commun. 142:38-46.

54. Yang, S. D., L. T. Ho, and T. J. Fung. 1988. Insulin induced activation and translocation of protein kinase $\mathrm{Fa}$ (a multifunctional protein phosphatase activator) in human platelet. Biochem. Biophys. Res. Commun. 157:61-69.

55. Swarup, G., K. V. Speeg, Jr., S. Cohen, and D. L. Garbers. 1982. Phosphotyrosyl-protein phosphatase of TCRC-2 cells. J. Biol. Chem. 257:7298-7301.

56. Swarup, G., S. Cohen, and D. L. Garbers. 1982. Inhibition of membrane phosphotyrosyl protein phosphatase activity by vanadate. Biochem. Biophys. Res. Commun. 107:1104-1109. 